\title{
5
}

\section{Enacting the Prevent Duty in Early Childhood Education Settings}

\author{
Jenny Robson
}

Abstract This chapter examines the implementation of the Prevent Duty in early childhood education (ECE) provision in England. Findings from a small-scale empirical study suggest that ECE practitioners simultaneously performed, resisted and embodied the requirements of the Prevent Duty in practice. ECE practitioners were performative in their response to the requirement to promote fundamental British values (FBVs) as they evidenced compliance within an environment of regulation. However, ECE practitioners simultaneously operated a pedagogy rich in values education in which children were positioned as constructors of values. The layering of counter-terrorism within safeguarding policy led to a repositioning of practices of surveillance of children and families, which resonates with some critical readings of counter-terrorism policy in ECE.

\footnotetext{
J. Robson ( $\square)$

Cass School of Education and Communities, University of East London, London, UK

e-mail: j.robson@uel.ac.uk 
Keywords Early childhood education $\bullet$ Counter-terrorism $\bullet$ Values education • Safeguarding $\bullet$ Fundamental British values

\section{Chapter Summary}

The Prevent Duty brought providers of publicly funded early childhood education (ECE) provision in England within the scope of the government's counter-terrorism strategy in 2015. Findings from a small-scale empirical study exploring the implementation of this new duty are discussed in this chapter. They show that enactment of the Prevent Duty within ECE provision was complex and multi-layered: practitioners simultaneously performed, resisted and embodied the Prevent Duty in their practice. Following a brief examination of the context, the chapter is structured into three parts: the response to fundamental British values (FBVs), values education in ECE and the implications of the alignment of Prevent with safeguarding policy.

Whilst ECE practitioners in this study were critical of FBVs from the perspective of their emphasis on Britishness, they evidenced compliance in order to meet the requirements of regulation. Visual displays designed by ECE practitioners to communicate FBVs are performative acts; however, the positioning of symbols of Britishness to represent values potentially obscured reflection on the associations such symbols may have with nationalism, colonialism and oppression. Values are central to relationships and the negotiation of knowledge in ECE and they shape everyday pedagogical practice. In this study, findings suggest that values in ECE remained distant from and unconstrained by FBVs. Children constructed and co-constructed values of relevance to their lives and their immediate issues of concern. This reflected a contextual moral pedagogy where children are positioned by ECE practitioners as competent in forming values. The alignment of safeguarding and counter-terrorism within ECE policy led to practices associated with preventing people being drawn into terrorism becoming synonymous with safeguarding children, legitimising new acts of surveillance. This chapter concludes by raising questions about the ways in which values and relationships between children, 
practitioners and families are governed by counter-terrorism policy. Such debates have the potential to provide a critical reading of counterterrorism strategy in the ECE sector.

\section{Context: Prevent and Early Childhood Education}

Policy development and implementation in ECE is not developed outside of 'real life' (Baldock, Fitzgerald, \& Kay, 2013) but is shaped by a social cultural context, where there is an increased emphasis on national security as a result of terrorist attacks and the subsequent loss of human life. ECE policy and debates surrounding policy implementation can be viewed as a 'sociocultural mirror' (New, 2009, p. 309). McKendrick and Finch (2016) suggest that there is a prevailing approach of strategies associated with securitisation across a range of child and family policy including, for example, enhanced practices of surveillance and that such policy is situated within a global narrative of a 'war on terror' (p. 3). Early childhood education settings, including childminders and nurseries, as registered early years childcare providers in England, came within the scope of the Prevent Duty if they delivered publicly funded provision for children aged from 2 to 4 (HMG, 2015 updated 2019).

The UK governments' policy response to terrorism had gradually shifted from a reactive to a preventative approach with an increased emphasis on work with communities (Panjwani, 2016). However, the implications and responsibilities arising from this shift for practitioners working with young children and families in communities remained ambiguous until the introduction of the Prevent Duty (Robson, 2019a). Lander (2016) argues that this new duty imposed a political agenda of securitisation onto practitioners working in community contexts and those working directly with children. Significantly, the ECE sector is now harnessed by statute to the government's counter-terrorism strategy (Robson, 2015) and practitioners working within registered early years childcare provision are constituted as both subjects and agents of state counter-terrorism policy (Robson, 2019a). 
The Prevent Duty placed two statutory requirements on the ECE sector; first, registered early years providers were required to promote a predetermined set of fundamental British values (FBVs) and, second, to identify those at risk of radicalisation. ECE policy designs lead to structures that promote accountability through regulation (Osgood, 2010). The Prevent Duty was reinforced through the Statutory Framework for the Early Years Foundation Stage (Department for Education, 2017). This policy sets out requirements across all aspects of ECE practice and providers are inspected by the state to assess their compliance with it. Similarly, the regulatory framework for education in England requires inspectors of registered early years provision to consider how well FBVs are promoted. Initially, this was part of the judgement on leadership and management (Ofsted, 2015) but in 2019 a revised regulatory framework changed the way the duty to promote FBVs is inspected in two ways. First, FBVs are situated within the judgement evaluating how the provision promotes children's personal development and, specifically, the extent to which the provider develops children's 'understanding of fundamental British values' (Ofsted, 2019a, p. 38).

Second, although FBVs remain a focus in the judgement on leadership and management, the new regulatory framework makes clear that leadership and management is inadequate where 'British values are not actively promoted in practice' (Ofsted, 2019a, p. 41). Furthermore, the 2015 Prevent Duty statutory guidance states that failure to promote FBVs in registered provision may lead to local authorities withdrawing early education funding (HMG, 2015). Through the inspection framework for ECE, the parallel policy agendas of counter-terrorism and safeguarding are aligned. Guidance on the inspection of safeguarding requires inspectors to assess how leaders create a culture of safeguarding; this includes how they keep 'children and learning safe from the dangers of radicalisation and extremism' (Ofsted, 2019b, p. 13). Regulation in this context is a practice of surveillance where inspectors assess compliance with the Prevent Duty and in doing so validate both FBVs and the practice of identifying families or individuals at risk of radicalisation. This raises questions about how ECE practitioners navigate the roles assigned to them by this powerful policy discourse of counter-terrorism, particularly the ways in which they evaluate the implications of the Prevent Duty for 
their relationship with children and families or question the relevance of FBVs to their pedagogical practice.

\section{Outline of Research Project}

This chapter draws on a small-scale empirical research study reported in Robson (2019a, b). Conducted within the interpretivist paradigm (Denzin and Lincoln, 2005), the study explored the multiple understandings of the Prevent duty operating in a small sample of six ECE providers in an ethnically diverse city in England. ECE settings were registered early years childcare providers subject to the Prevent Duty. There is a diversity of terminology applied in policy, practice and research in the study of the education and care of young children (Lloyd, 2012). The term 'early childhood education' is used here to describe publicly funded early education and care for young children that are provided by registered early years providers who are private enterprises or not for profit organisations. Participants in this study included ECE practitioners with responsibility for leadership of pedagogy and ECE practice and children (aged two to four). Data was collected through semi-structured interviews with practitioners and walking tours of the provision with children and practitioners. During the walking tours, participants shared documentation emerging from their engagement with the curriculum and pedagogy in the setting. As this was a small-scale study the findings arising from the analysis of data are intended to raise questions about, and provide insights into, the implementation of the Prevent Duty within a specific context. The findings, therefore, cannot be generalised across all ECE settings in England. In the discussion that follows, pseudonyms are used for all participants and the ECE settings in order to maintain anonymity. 


\section{The Performance of Fundamental British Values in Early Childhood}

The emphasis placed on Britishness in FBVs was contested by the ECE practitioners. They questioned the relevance of an instituted form of Britishness to children, their families and the practitioners in the nursery. Specifically, practitioners appeared troubled that the diverse histories, nationalities and ethnic backgrounds of children and families within the ECE provision may not be considered British or that the families may not identify themselves with the specific version of Britishness represented in the policy of FBVs. One ECE practitioner stated:

I don't think some children and families would see themselves as British. If I go home and say to my Mum 'I am British' she would say 'No you are not you are...' We have been given FBV as a tool to work with, but a lot of people would question FBV because they would not see themselves as British. (Sandra, Little House Day Nursery)

Sandra's perspective reflected the complexity of individual identities and histories within the practitioner group and the way this affected their enactment of the policy. The ECE practitioners' questioning of Britishness resonates with the critique of FBVs in the broader literature concerned with primary and secondary education. For example, Lander's (2016) analysis queries whether FBVs can be claimed as uniquely British or whether there is an assumption in the Prevent Duty that FBVs are shared by all citizens.

Representations of FBVs in resources were challenged by ECE practitioners, reflecting recent critical perspectives in the literature where materials used to promote FBVs were found to 'rarely trouble the nature of the values or which present them in ways that are simplistic and formulaic' (Revell \& Bryan, 2018, p. 13). In the Grand House Day Nursery practitioners were critical in their approach to resources produced commercially to support ECE providers in implementing FBVs. One ECE practitioner reflected: 
A lot of the resources we saw on line were posters that had a British flag on it. Our children are not from a British background and we did not want to display something that did not belong to them. We did not want to display the flag. The posters had the Queen's face and how did that relate to the [young] children? (Rebecca, Grand House Day Nursery)

Symbols such as the Union Flag and the monarchy were considered as patriotic and nationalistic; many practitioners suggested that they were decontextualized from children's lives and therefore irrelevant. The criticality evidenced by the ECE practitioners is significantly different to that Moncrieffe and Moncrieffe found in primary school teachers, who endorsed images to represent FBVs and maintained 'the power of exclusive monocultural white identities and perspectives' (2019, p. 66.). The ECE practitioners identified that FBVs are represented in and by the symbols of civic life in resources available to ECE settings for purchase. Symbols of Britishness, now aligned to national values, are considered by the ECE practitioners as an exclusionary force. An alternative perspective on national values is provided by Soutphommasane (2012 also cited by Vincent, 2019); he proposed that a 'shared national identity' is characterised by 'reciprocity and cooperation' enabling a 'community of shared belief' (pp. 71-72). Within this approach national identity emerges through a shared public culture represented in institutions and values; this is a dynamic process of debate opening possibilities for dialogue and new interpretations of national values. However, FBVs are perceived and experienced by the ECE practitioners as an imposed emblem of Britishness distant from their practice.

While the ECE practitioners challenged the appropriateness of particular and imposed views of Britishness, their responses to FBVs were complex and sometimes contradictory (Robson, 2019a). Despite the criticality evident above, the walking tours with the ECE practitioners in the settings revealed that there were displays about FBVs in the settings. Such displays generally included the names of the four FBVs and the Union Flag together with some information about the practices that realised the value. For example, in Grand House Nursery, the display stated that the practice of role modelling behaviours was linked to the rule of law. Similarly, the practices of children's planning meetings and 
children's role in setting up their activities were linked to democracy. In Arcade Day Nursery, the display in the reception area included a statement of how the values of the nursery mapped across to FBVs. Vincent (2019) suggested that this approach to the promotion of FBVs takes the form of 'Representing Britain' (p. 23) where displays listing the FBVs have Union Flag decoration and symbols associated with Britain. All the ECE practitioners referred to their displays in the context of regulation and the requirement to provide evidence during the inspection visit that they were promoting FBVs. The ECE practitioners understood this to be important because, at the time of the fieldwork, the degree to which the setting promoted FBVs formed part of the inspection judgement on leadership and management in the provision. Although the displays gave some insight into how the provision was meeting its statutory obligations, they were afforded low status by the ECE practitioners relative to other aspects of the visual environment that reflected the everyday practice with children and children's engagement with learning. Most of the ECE practitioners were apologetic in introducing the displays about FBVs; it was as if they considered them outside of their ECE practice.

The displays formed part of a deliberate strategy on the part of the ECE practitioners to evidence compliance with the requirement to promote FBVs. They can be considered as performative acts by the practitioner (Butler, 1997; Osgood, 2006). The ECE practitioners here are performatively constituted; they are subject to the duty to FBVs, and they perform this duty in order to avoid the negative consequences arising from an inadequate inspection judgement. However, my analysis of the daily practice of values education (discussed later in the chapter) reveals how the ECE practitioners intervene and disrupt the hegemonic discourse of FBVs through the pedagogy in early childhood. FBVs are performed in a specific way for the purpose of inspection and this reflects the power of surveillance through inspection. Farrell (2016) in an analysis of FBVs in the context of schools concluded that teachers are required to 'be surveilled in the truth game of Britishness,' (p. 14) and this highlights the reach of FBVs as a practice of power deployed in early childhood and sustained through all sectors of education. While the practitioners provided a consistent rationale for an explicit public commitment to FBVs, this performativity may have obscured reflection on 
the ways in which values are communicated within ECE through the material environment (Johansson \& Puroila, 2016). For some practitioners, families and children the imagery associated with FBVs, explicitly the Union Flag and the monarchy, may be considered as symbols of nationalism, colonialism, oppression and power. The visual representation of FBVs by the ECE practitioners contrasted with the highly critical perspective they adopted towards the symbols of Britishness in commercially available resources to support the implementation of FBVs in nurseries. The complexity of ECE practitioners' response to FBVs is now explored further by examining the ways in which they deployed pedagogies of values education.

\section{Values Education in Early Childhood and Fundamental British Values}

Values education is a complex concept in early childhood; it can be understood as an education practice through which children are assumed to learn values as well as the norms and skills reflected in those values (Halstead \& Taylor, 2000). Values are 'guiding principles in life' (Schwartz, 2012, p. 17) and they are ideals that enable the 'evaluation of beliefs and actions' (Halstead, 1996, p. 5). In this way, they form the basis of moral judgements in determining what is legitimate or unjustifiable and appropriate or inappropriate. Within research, policy and practice the focus on values in ECE pre-dates the introduction of the Prevent Duty and the requirement to promote FBVs.

Supra-national organisations advocating for the development of national policy and practice frameworks in ECE have emphasised the centrality of values. UNESCO (2000) claims that the 'value orientations of children are largely determined by the time they reach the age of formal schooling' (p. 2) and therefore state governments need to create a 'value-based environment' (p. 4) in early childhood provision together with a child-centred values education programme that is free from political, social or religious abuse. Osler (2015) and UNESCO (2015) emphasise the centrality of values, for example fairness, empathy and respect, in 
developing understandings of citizenship and a sense of belonging to a community. Elsewhere (Robson, 2019a) I have raised the question as to whether the policy of promoting FBVs in ECE can be separated from the political context of measures to address counter-terrorism or indeed whether the promotion of FBVs is considered by the UK government as a values education programme.

The ECE practitioners in this study were subject to the Statutory framework for the early years foundation stage (DFE, 2017); however, this framework for curriculum and pedagogy omits any mention of FBVs or clarification of how FBVs relates to both the 'areas for learning and development' and the 'early learning goals' (p. 10). The framework states that registered providers of ECE are subject to the Prevent Duty. This layering of counter-terrorism policy over the statutory framework for ECE creates ambiguity, tension and complexity for ECE practitioners as they enact policy in practice (Robson \& Martin, 2019) and more explicitly the pedagogical relationships that exist in ECE between practitioners and children and between children (Robson, 2019b).

This problem can be situated in broader debates about the nature of values education, which often revolve around the central question as to whether values should be 'instilled' in children or whether children should be taught 'to explore and develop their own values' (Halstead, 1996, p. 9). In practice, such values can be explicit, where it is directed by the state through the curriculum or other policy texts, or implicit within the practices of ECE (Thornberg, 2016). Einarsdottir et al. (2015), researching in a Nordic context, argue that practitioners are commissioned by state governments to mediate values that are formulated in the political arena; however, values are also embedded within the pedagogy of ECE (Emilson \& Johansson, 2009). Values education, as a pedagogical practice, mediates moral and political values to children (Thornberg, 2016) and therefore moral pedagogies provide an understanding of how FBVs are navigated in ECE practice in England. Basourakos (1999) proposes a theory for values or moral education that contrasts conventional moral pedagogy and a contextual moral pedagogy. In the former, values are absolute and the role of the ECE practitioner is to transmit a predetermined set of values to children. FBVs as a set of values specified by the state in national policy assume a conventional moral pedagogy 
(Robson 2019a, b). However, a contextual moral pedagogy leads to a paradigmatic shift where the ECE practitioners engage children in constructing their own understanding of moral values and practices. The ECE practitioners I interviewed stated:

FBV are not asking us to do anything differently but bringing it out more. So, do what you are doing but extending it more. They [values] are really important - what we are teaching the children will have an impact when they are older. (Sandra, Little House Nursery)

The values have always been here. The focus on Fundamental British Values has made us more serious about them. (Farah, Arcade Day Nursery)

Here Sandra reflected that values had always been implicit in the pedagogical practice and her understanding was that FBVs did not bring about a change in practice. However, Farah and Sandra emphasised that the requirement to promote FBVs led to an increased focus on values education; this was a consistent theme emerging from the interview data where the practitioners indicated there was a heightened awareness of the practice of values education.

ECE practitioners named pedagogical practices that enabled a focus on values education, for example, the forums enabling children's participation in the weekly and daily planning of the curriculum and learning activities. Labelled by the practitioners as 'children's planning meetings' such forums were led and documented by children. The visual records of the meeting were displayed as a way of validating and celebrating children's contributions to the planning. In naming the values observed in children's planning meetings practitioners principally focused on those included within the four FBVs. However, my analysis revealed a rich diversity of values operating in children's planning meetings including for example, care, kindness, empathy, solidarity, respect and joy. Practitioners stated that the planning meetings provided opportunities for children to learn about democracy as an FBV and specifically about democratic relationships between children and between children and adults. However, this practice moved beyond a rhetorical commitment to democracy by applying democracy as a principle to guide pedagogical relationships in 
ECE. Einarsdottir et al. (2015) understand this practice as a lived democracy' (p. 104) where children's everyday experience is a democratic process. The practitioners' pedagogy of implicit values education, where values are explored within the everyday practice (Halstead, 1996), enabled children to experience values beyond the four FBVs. Although children's engagement in values education is unconstrained by the narrow focus of FBVs, practitioners appeared constrained by the four FBVs when reflecting on the values implicit in children's planning meetings. In this way the practitioners perform the legitimised FBVs.

Values education was sustained within the everyday practice of the setting. In Big House Day Nursery, relationships between children, families and communities were explored as part of the area of learning 'Understanding the World' within the Statutory Framework for the Early Years Foundation Stage (DFE, 2017). The decision to focus on exploring relationships as 'Kindness in the Community' was made by the children and practitioners as it was significant to their relationships; this was evident from the documentation emerging from the children's planning meetings. The ECE practitioners commented that kindness as a concept and value was accessible and meaningful to children. While kindness as a value is not one of the four FBVs it had high relevance to the relationships between children, families and communities and my analysis suggests that it led children to a deeper exploration of other values such as empathy, care, compassion and appreciation of diversity in the community. Children made and subsequently shared tokens of kindness with a range of people in the vicinity of the ECE provision including the homeless people they met every day, people who worked in local shops or in the public transport stations. They visited the Mosque after Friday Prayers to distribute tokens of kindness. Here, children's learning about values is contextualised within the social and cultural environment of the ECE provision and its wider community (Johansson \& Puroila, 2016). Children constructed their understanding of kindness through lived experience. My analysis revealed that ECE practitioners lifted to the foreground the four FBVs in their dialogues about pedagogical practice. This resonates with Johansson's (2011) suggestion that values may be communicated consciously in ECE provision. However, the reality of values education went beyond the compliance to and performance of FBVs; the 
ECE practitioners engaged children in a contextual moral pedagogy where they are constructors of values and unconstrained by the narrow focus of the four FBVs. Viewed through this perspective, values education in early childhood extends beyond the UK government's explicit policy rationale for FBVs of counter-terrorism and national security.

\section{The Securitisation of Safeguarding?}

The Statutory Framework for the Early Years Foundation Stage (DFE, 2017) sets out the safeguarding and welfare requirements that providers of ECE must take to 'keep children safe and promote their welfare' (p. 5), including having due regard to the Prevent Duty. Similarly, within the guidance on inspection of safeguarding in early years settings 'radicalisation and/or extremist behaviour' is included as one of the areas of concern where practitioners may need to take safeguarding action (Ofsted, 2019b, pp. 5-6). By positioning counter-terrorism as part of safeguarding policy, the practices associated with preventing people from being drawn into terrorism become aligned with safeguarding. I suggest this is an evolving process of securitisation of safeguarding practice in ECE, where securitisation is the process by which the law requires practitioners to enact the demands of national security (Gearon, 2015). In this way safeguarding policies, as practices of power, produce rules that organise and guide ECE practice (see Chap. 3).

The ECE practitioners revealed a story of their initial encounters with the Prevent Duty. Farah stated that she first became aware of the Prevent Duty when she participated in safeguarding training, which included information about the threat of terrorism and terrorist-related incidents in their locality.

I first heard of it [Prevent] on my safeguarding course and they explained that the characteristics of radicalisation are more common now and they emphasised the dangers. (Farah, Arcade Day Nursery)

This situated the training as dealing with the threat of terrorism rather than the risk to the individual child or families arising from 
radicalisation. Nargis and Sacha understood and accepted that safeguarding practice had been extended to include a focus on identifying families at risk of radicalisation:

The idea came along in 2015 and we had training. The children love telling you things and you might hear something that rings a bell. Talk to the safeguarding officer. If they are going on holiday - where are they staying? Yes, it is part of safeguarding. (Nargis, Angel Community Nursery)

We had a few trainings about safeguarding - some of the things [observation] we naturally do. (Sacha, Big House Day Nursery)

These practitioners indicated there had not been opportunities to reflect on the implications arising from this extension of safeguarding practice. Whilst I am not questioning the importance of keeping children safe from radicalisation and extremist behaviour, the implications arising from the fusion of these two policy agendas within ECE practice is, I suggest, problematic in two ways and this is explored further below.

First, although ECE practitioners already engage in practices of observation of families as part of safeguarding the welfare of children, the Prevent Duty extends the focus of surveillance to include identification of families or their colleagues at risk of radicalisation. The ECE practitioners, in this study, appear to have an unquestioning acceptance of this shift in practice.

...it is to prevent children from being dragged into terrorism or it can be adults. It is not just with children it is with staff and parents as well. We always have to look out for it. (Farah, Arcade Day Nursery)

We have a duty of care and we have to be aware when we observe children's play or staff and how to raise concerns. We have to be mindful and keep an eye out. I think it comes with knowing the children and noting any changes in their behaviour. Also being confident. (Rosa, Little Castle Community Nursery)

I suggest that the absence of opportunities for reflection on this layering of policy and practice is problematic as there are potential implications 
for practice, particularly as ECE practitioners enact the demands of national security policy, in pedagogical relationships with families (and this is explored further below). Mary and Sacha actively engaged in surveillance of children, families and colleagues for potential signs of radicalisation and this was embedded in daily practice within the ECE provision.

It is our duty of care to report anything that we may be concerned about with regard to radicalisation or if the child or the family are at risk of radicalisation. If there have been any prolonged absences or any language that the children are using. Trips to certain parts of the world and if they do not return on the date in which they had said. It is our duty to report these concerns. (Mary, Grand House Day Nursery)

In the early years sector it is more about absences and monitoring those absences because with quite young children they are not necessarily going to be drawn into terrorism but their families, their siblings and their wider community. We record all absences and we will contact the parents and ask them where they were and ask them what was happening. If we were informed that they had taken the children away unexpectedly then we would inform the manager and the safeguarding lead for the organisation. If we are observing children as we do every day, we would notice any changes in their behaviour and anything they would be mentioning. (Sacha, Big House Day Nursery)

The ECE practitioners absorbed this new aspect of surveillance into their practice just as Vincent (2019) observed teachers in primary and secondary schools absorb FBVs into the curriculum and pedagogical practice. In these ECE settings the Prevent Duty had established a narrative that positioned all children, families and colleagues as being at risk of radicalisation or as potential terrorists; this narrative was legitimised through its inclusion within the powerful mandate of safeguarding policy and practice.

Second, the way in which the Prevent Duty positions ECE practitioners in relation to children and their families is potentially in conflict with other guidance that governs their practice. One of the stated aims of the Early Years Foundation Stage (DfE, 2017) is to provide 'partnership 
working between practitioners and with parents/carers' (p. 5) enabled by a statutory requirement for each child to have a key person whose responsibilities include 'to engage and support parents and/or carers in guiding their child's development at home.' (p. 10). Central to this pedagogical relationship between practitioners, children and families is the mutual concern for the learning and care of the child. However, the national priority for counter-terrorism intrudes into this space and further extends the process of securitisation of early childhood practice. The ECE practitioners felt compelled to 'look out for it [signs of radicalisation]' (Farah) or 'keep an eye out [for potential terrorists]'(Rosa) in their work with children and families. Central to this practice of surveillance was to view everyday occurrences, for example, absence from the nursery or children's speech; through the lens of terrorism. In this way counter-terrorism became a focus in the pedagogical relationships between families and the ECE practitioners. My research brings into question the way the Prevent Duty affects the role of ECE provision in the community. Dahlberg, Moss, and Pence (2013) argue that early childhood institutions are forums 'where children and adults may participate together in projects of social, cultural, political and economic significance' (p. 80). They suggest that one such significant project arises 'from its potential for the establishment and strengthening of social networks of relationships between children, between adults (both parents and other adults engaged in the institution) and between children and adults' (pp. 84-85) where ECE providers can contribute to the cohesion of local communities. A focus for further research on the implementation of the Prevent Duty emerges from this perspective; this could explore how social networks operating within and around ECE provision are potentially affected by practices of surveillance whose aim is identify those at risk of radicalisation.

\section{Conclusion}

The introduction of the Prevent Duty in ECE has potentially far reaching implications for practice in England. Through the intersection of policies concerned with counter-terrorism, early childhood education and care and safeguarding ECE practitioners are influenced by the powerful 
discourse surrounding measures to counter-terrorism. The research reported in this chapter brings to the foreground two areas for further debate in the ECE sector: first, the role of values and second, the nature of risk being safeguarded against. FBVs are a pre-determined and explicit set of values and as such they assume values can be transmitted to children (Robson, 2019a). As values formulated in the political arena and at some distance from ECE practice, FBVs may be in tension with the values implicit within the everyday pedagogical practice in ECE. Practitioners in the ECE sector are placed under pressure to comply with the policy of FBVs and this may compromise their beliefs about appropriate values education in early childhood. A consideration of the role of children as constructors or co-constructors of values may lead to a deeper understanding of the richness and diversity of values that are central to children's lives. Through this process alternative narratives about values education may emerge that are not constrained by the narrow focus of FBVs or the performativity associated with evidencing compliance.

Second, the requirement to identify those at risk of radicalisation through practices of surveillance has the potential to affect relationships in ECE. This study has revealed how the focus of practices associated with safeguarding has been extended from a focus on children's welfare to include the identification of families and practitioners at risk of radicalisation. Everyday occurrences within the ECE setting and in relationships with families were viewed through the powerful narrative of counterterrorism. Alternative strategies to prevent people being drawn into terrorism may emerge if there is a focus on how ECE provision may initiate, develop and sustain social networks of relationships that could contribute to cohesion in the local community. Such a reflection may deflect the focus on the individual as an object of risk and refocus on structural issues of inequality and injustice that may be experienced by young children and their families.

This chapter contributes to a growing field of scholarship examining the implications arising from the Prevent Duty for practitioners working with children and their family. Research reported in this chapter makes a small contribution to the field in three ways; first, it gives visibility to the process of securitisation where ECE practitioners are required to enact the requirements of national security policy in their everyday practice. 
Second, the status and pedagogy of values education as an everyday practice in ECE is revealed as unconstrained by the hegemonic narrative of state specified values in the FBVs. The contextual moral pedagogy that underpinned values education positions children as capable constructors of values which they apply to evaluate actions and events. Applied in this way pedagogy becomes a powerful tool for producing alternative narratives on values to those prescribed in policy. Third, this chapter reveals the complex way in which the ECE practitioners in this study implemented the Prevent Duty; this was simultaneously performed, resisted and embodied in their pedagogy and engagement with colleagues, children and their families.

\section{References}

Baldock, P., Fitzgerald, D., \& Kay, J. (2013). Understanding early years policy (3rd ed.). London: Sage Publications.

Basourakos, J. (1999). Moral voices and moral choices: Canadian drama and moral pedagogy. Journal of Moral Education, 28(4), 473-489.

Butler, J. (1997). Excitable speech: A politics of the performative. London: Routledge.

Dahlberg, G., Moss, P., \& Pence, A. (2013). Beyond quality in early childhood education: Postmodern perspectives. Abingdon, UK: Routledge.

Denzin, N. K., \& Lincoln, Y. S. (Eds.). (2005). Strategies of qualitative inquiry (3rd ed.). London: Sage Publications.

DfE. (2017). Statutory framework for the early years foundation stage. London: Department for Education. Retrieved from www.gov.uk/government/publications/early-years-foundation-stage-framework\%2D\%2D2

Einarsdottir, J., Purola, A. M., Johansson, E. M., Broström, S., \& Emilson, A. (2015). Democracy, caring and competence: Values perspectives in ECEC curricula in the Nordic countries. International Journal of Early Years Education, 23(1), 97-114.

Emilson, A., \& Johansson, E. (2009). Communicated values in teacher and toddler interactions in preschool. In D. Berthelsen, J. Brownlee, \& E. Johansson (Eds.), Participatory learning and the early years (pp. 61-77). New York: Routledge and Taylor \& Francis Group. 
Farrell, F. (2016). Why all of a sudden to do we need to teach fundamental British values? A critical investigation of religious education student teaching positioning within a policy discourse of discipline and control. Journal of Education for Teaching, 42(3), 1-18.

Gearon, L. (2015). Education, security and intelligence studies. British Journal of Educational Studies, 63(3), 263-279.

Halstead, J. M. (1996). Values and values education in schools. In J. M. Halstead \& M. J. Taylor (Eds.), Values in education and education in values (pp. 3-14). London: Falmer Press.

Halstead, J. M., \& Taylor, M. J. (2000). Learning and teaching about values: A review of recent research. Cambridge Journal of Education, 30(2), 169-202.

HM Government (HMG). (2015). Prevent duty guidance: For England and Wales. London: HM Government.

HMG. (2015 Updated 2019). Revised prevent duty guidance: For England and Wales. Retrieved from www.gov.uk/government/publications/prevent-dutyguidance/revised-prevent-duty-guidance-for-england-and-wales\#e-sectorspecific-guidance

Johansson, E. (2011). Moral discoveries and learning in preschool. In N. Pramling \& I. Pramling Samuelson (Eds.), Educational encounters: Nordic studies in early childhood didactics (pp. 127-139). Dordrecht, The Netherlands: Spring Science and Business Media.

Johansson, E., \& Puroila, A. M. (2016). Values education in Nordic preschools: Theory and practice. International Journal of Early Childhood, 48(2), 133-135.

Lander, V. (2016). Introduction to fundamental British values. Journal of Education for Teaching, 42(3), 274-279.

Lloyd, E. (2012). Childcare markets: An introduction. In E. Lloyd \& H. Penn (Eds.), Childcare markets: Can they deliver an equitable service? (pp. 3-18). Bristol, UK: Policy Press.

McKendrick, D., \& Finch, J. (2016). 'Under heavy manners?': Social work, radicalisation, troubled families and non-linear war. British Journal of Social Work, 47(2), 308-324.

Moncrieffe, M., \& Moncrieffe, A. (2019). An examination of imagery used to represent fundamental British values and British identity on primary school display boards. London Review of Education, 17(1), 52-69.

New, R. S. (2009). ECE policies (and policy debates) as a sociocultural mirror. Contemporary Issues in Early Childhood, 10(3), 309-311.

Ofsted. (2015). Early years inspection handbook. London: Ofsted. Retrieved from https://assets.publishing.service.gov.uk/government/uploads/system/ 
uploads/attachment_data/file/596329/Early_years_inspection_ handbook.pdf

Ofsted. (2019a). Early years inspection handbook for Ofsted registered provision. Retrieved from https://assets.publishing.service.gov.uk/government/uploads/ system/uploads/attachment_data/file/828465/Early_years_inspection_ handbook.pdf

Ofsted. (2019b). Inspecting safeguarding in early years education and skills settings. Retrieved from: https://assets.publishing.service.gov.uk/government/ uploads/system/uploads/attachment_data/file/828763/Inspecting_ safeguarding_in_early_years_education_and_skills.pdf

Osgood, J. (2006). Deconstructing professionalism in early childhood education: Resisting the regulatory gaze. Contemporary Issues in Early Childhood, $7(1), 5-14$.

Osgood, J. (2010). Reconstructing professionalism in ECE: The case for the 'critically reflective emotional professional'. Early Years, 30(2), 119-133.

Osler, A. (2015). Human rights education, postcolonial scholarship, and action for social justice. Theory \& Research in Social Education, 43(2), 244-274.

Panjwani, F. (2016). Towards an overlapping consensus: Muslim teachers' views on fundamental British values. Journal of Education for Teaching, 42(3), 329-340.

Revell, L., \& Bryan, H. (2018). Fundamental British values in education: Radicalisation, national identity and Britishness. Bingley, UK: Emerald Publishing.

Robson, J. V. K. (2015). Fundamental British values in the early years. Retrieved from www.consider-ed.org.uk/fundamental-british-values-in-the-early-years-adilemma-for-the-sector/

Robson, J. V. K. (2019a). How do practitioners in early years provision promote fundamental British values? International Journal of Early Years Education, 27(1), 95-110.

Robson, J. V. K. (2019b). Participatory pedagogy for values education in early childhood education. European Early Childhood Education Research Journal, 27(3), 420-431.

Robson, J. V. K., \& Martin, E. (2019). How do early childhood education leaders navigate ethical dilemmas within the context of marketised provision in England? Contemporary Issues in Early Childhood, 20(1), 1-11.

Schwartz, S. H. (2012). An overview of the Schwartz theory of basic values. Online Readings in Psychology and Culture, 2(1). https://doi. org/10.9707/2307-0919.1116 
Soutphommasane, T. (2012). The virtuous citizen: Patriotism in a multicultural society. Cambridge, UK: Cambridge University Press.

Thornberg, R. (2016). Values education in Nordic preschools: A commentary. International Journal of Early Childhood., 48(2), 241-257.

UNESCO. (2000). Framework for action on values education. Paris: UNESCO.

UNESCO. (2015). Global citizenship education. Paris: UNESCO.

Vincent, C. (2019). Cohesion, citizenship and coherence: Schools' responses to the British values policy. British Journal of Sociology of Education, 43(1), 17-32.

Open Access This chapter is licensed under the terms of the Creative Commons Attribution 4.0 International License (http://creativecommons.org/licenses/ by/4.0/), which permits use, sharing, adaptation, distribution and reproduction in any medium or format, as long as you give appropriate credit to the original author(s) and the source, provide a link to the Creative Commons licence and indicate if changes were made.

The images or other third party material in this chapter are included in the chapter's Creative Commons licence, unless indicated otherwise in a credit line to the material. If material is not included in the chapter's Creative Commons licence and your intended use is not permitted by statutory regulation or exceeds the permitted use, you will need to obtain permission directly from the copyright holder.

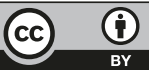

